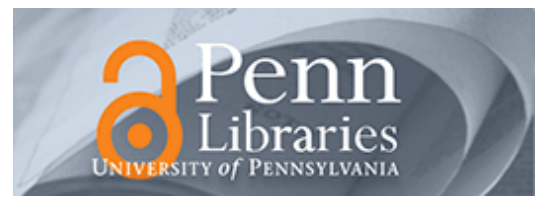

University of Pennsylvania

ScholarlyCommons

10-23-2012

\title{
A Dubious Export: The Moral Perils of American-Style Ethics Consultation
}

Autumn Fiester

University of Pennsylvania, fiester@mail.med.upenn.edu

Follow this and additional works at: https://repository.upenn.edu/bioethics_papers

Part of the Bioethics and Medical Ethics Commons

\section{Recommended Citation}

Fiester, A. (2012). A Dubious Export: The Moral Perils of American-Style Ethics Consultation. Bioethics, 27 (1), ii-iii. http://dx.doi.org/10.1111/bioe.12011

This is the peer reviewed version of the following article: A Dubious Export: The Moral Perils of American-Style Ethics and Consultation, Bioethics, 27, 1, ii-iii, January 2013, which has been published in final form at dx.doi.org/ 10.1111/bioe.12011. This article may be used for non-commercial purposes in accordance With Wiley Terms and Conditions for self-archiving.

This paper is posted at ScholarlyCommons. https://repository.upenn.edu/bioethics_papers/75

For more information, please contact repository@pobox.upenn.edu. 


\section{A Dubious Export: The Moral Perils of American-Style Ethics Consultation}

\section{Keywords}

clinical ethics; consultation; mediation; professional standards

\section{Disciplines}

Bioethics and Medical Ethics | Medicine and Health Sciences

\section{Comments}

This is the peer reviewed version of the following article: A Dubious Export: The Moral Perils of AmericanStyle Ethics and Consultation, Bioethics, 27, 1, ii-iii, January 2013, which has been published in final form at dx.doi.org/10.1111/bioe.12011. This article may be used for non-commercial purposes in accordance With Wiley Terms and Conditions for self-archiving. 
A Dubious Export: The Moral Perils of American-Style Ethics Consultation

Autumn M. Fiester, Ph.D.

Department of Medical Ethics \& Health Policy

Perlman School of Medicine at the University of Pennsylvania

3401 Market Street - Suite 320

Philadelphia, PA 19104-3319

Telephone 215-573-2602

Fax 215-573-4046

fiester@mail.med.upenn.edu 


\section{A Dubious Export: The Moral Perils of American-Style Ethics Consultation Autumn Fiester, PhD}

American-style ethics consultation is only the latest bioethical export from the United States. Having achieved a near-universal foothold in American hospitals over the last thirty years, Ethics Consultation Services (ECSs) have been making their way across the Atlantic for the last ten. ${ }^{1}$ But American ECSs are not the unqualified good they promised to be: While many of the services they provide undoubtedly do significant good in assisting patients, families, and clinical staff, other roles they play are ethically questionable. Hospitals currently considering the formation and role of a new ECS would be well advised to engage in critical, reflective debate on both the merits and liabilities of the institution they are importing.

Ethics Consultation Services (ECSs) exist in $81 \%$ of American hospitals and an additional $14 \%$ are in the process of forming them. ${ }^{2}$ The role of the hospital ethics committee varies widely by institution, but many of the functions they perform are laudable services to patients, families and providers: e.g., mediating conflict between stakeholders with different points of view; facilitating difficult conversations or improving communication between stakeholders; laying out options that had not previously been considered; creating hospital policies; clarifying relevant legal regulations; or helping to illuminate the relevant principles or values of the stakeholders. ${ }^{3}$ But one role played by many US ECSs is ethically problematic: they

\footnotetext{
${ }^{1}$ M. Pfäfflin, K. Kobert \& S. Reitertheil. Evaluating Clinical Ethics Consultation: A European Perspective. Camb $Q$ Healthc Ethics 2009; 18: 406-419.

${ }^{2}$ E. Fox E, S. Myers \& R.A. Pearlman. Ethics Consultation in United States Hospitals: A National Survey. Am $J$ Bioeth 2007; 7: 13-25.

${ }^{3}$ D.J. Casarett , F. Daskal \& J. Lantos. The Authority of the Clinical Ethicist. Hastings Cent Rep 1998; 28: 6-11; M.P. Aulisio, R.M. Arnold \& S.J. Youngner. A Position Paper from the Society for Health and Human ValuesSociety for Bioethics Consultation Task Force on Standards for Bioethics Consultation. Health Care Ethics Consultation: Nature, Goals, and Competencies. Ann Intern Med 2000; 133: 59-69; Keeping Moral Space Open. New Images of Ethics Consulting. Hastings Cent Rep 1993; 23: 33-40; American Society for Bioethics and Humanities. 2011. Core Competencies for Healthcare Ethics Consultation, 2nd edition. Glenview, IL.
} 
choose sides in values-based conflicts, over-stepping the legitimate bounds of their expertise or right.

One of the troubling facts about ethics consultation in the US today is that many individuals conducting ethics consults have no formal ethics training. Not even half of consultants in the US have been trained through direct supervision, and only $5 \%$ have completed graduate work in ethics. ${ }^{4}$ To remedy this problem, there are efforts underway in the US to better train, and even credentialize, ECSs. ${ }^{5}$ But the current lack of qualifications among consultants only exacerbates the more insidious ethical problem in many ECSs that no amount of training can surmount: they make recommendations with regard to who is "right" and "wrong" in a clinical ethics dispute without the moral authority to do so. .

How often do such judgments occur? The most thorough national study to date of the actions taken by US ECSs found extremely wide variation on this issue. ${ }^{6}$ While $25 \%$ of ECSs never determine a single best course of action, a full half of ECSs recommend a single best course of action at least $50 \%$ of the time. On average, US ECSs define the right course of action in more than $40 \%$ of all cases.

So what is wrong with an ethics committee determining a single right course of action in an ethics dispute? Let's reflect on what is happening in an ethical conflict that has two opposing sides. Two or more stakeholders have taken conflicting positions that are anchored by

\footnotetext{
${ }^{4}$ E. Fox, S. Myers \& R.A. Pearlman, op. it. note 2, p. 17. In fact, doubt about the qualifications of ethics consultants is one reason why American physicians are reluctant to use their institution's ECS. See G. DuVal, B. Clarridge, M.S. Gensler \& M. Danis. A National Survey of U.S. Internists' Experiences with Ethical Dilemmas and Ethics Consultation. J Gen Intern Med 2004; 19: 251-258.

${ }^{5}$ N.D. Dubler, M.P. Webber, D.M. Swiderski and the Faculty and the National Working Group for the Clinical Ethics Credentialing Project. Charting the Future. Hastings Cent Rep 2009; 39: 29-33; R. Orr and W. Shelton. A Process and Format for Clinical Ethics Consultation. J Clin Ethic 2009; 20 (1): 79-89; M. Smith, et al. Toward Competency-Based Certification of Clinical Ethics Consultants: a Four-Step Process. J Clin Ethic 2010; 21 (1): 1422; K. Kipnis. The Certified Clinical Ethics Consultant. HEC Forum 2009; 21 (3): 249-261; Clinical Ethics Consultation Affairs Committee. 2010. CECA report to the Board of Directors, ASBH on Certification, Accreditation, and Credentializing of Clinical Ethics Consultants. Available at: http://www.asbh.org/uploads/files/ceca\%20c-a\%20report\%20101210.pdf [Accessed 27 Aug 2012].

${ }^{6}$ E. Fox, S. Myers \& R.A. Pearlman, op. it. note 2, at 18.
} 
deeply held moral convictions and values. A third-party choice of one side over the other could only be ethically justified if it were based on moral expertise that endows the ethics consultant with an ability to rank the values of the various stakeholders. But who possesses this type of moral knowledge? You might say, the moral philosopher, and there is a large literature engaging that very question. Although some philosophers are skeptical of any claim to expertise, ${ }^{7}$ the predominant view among moral philosophers is that, at best, the kind of expertise one gets from studying ethics only enables one to identify and assess the ethical arguments or core values at stake ${ }^{8}$, not to authoritatively adjudicate among them. Philosophers often claim an expert skill of "coaching" $"$ others in their moral reflections, but employ a hardline "disavowal of any claims by clinical ethics consultants to some unique access to moral truth." ${ }^{10}$ Deciding who is right in an ethics dilemma operates on the false pretense of possessing moral truth, of having knowledge about how to hierarchize values when no such knowledge exists. The legal case of the American Terri Schiavo ${ }^{11}$ and the controversy over the suicide of British couple Penelope and Peter Duff at the Dignitas Clinic ${ }^{12}$ demonstrate the kind of values-pluralism that makes claims of third-party ethical authority specious at best. When ECSs render a judgment about which side is morally correct, they exceed the limit of their actual expertise.

\footnotetext{
${ }^{7}$ T. Engelhardt Jr. The Ordination of Bioethicists as Secular Moral Experts. Soc Philos Policy 2002; 19: 59-82; C. Cowley. Expertise, Wisdom, and Moral Philosophers: A Response. Bioethics 2012; 26 (6): 337-342.

${ }^{8}$ B. Gesang. Are Moral Philosophers Moral Experts? Bioethics 2010; 24 (4): 153-159.

${ }^{9}$ A. Follesdall. 2004. The Philosopher as Coach. In Experts in Science and Society. E. Kurz-Milcke \& G. Gigerenzer, eds. New York: Kluwer Academic: 181-199; D. Archard. Why Moral Philosophers Are Not and Should Not Be Moral Experts. Bioethics 2011; 25 (3): 119-127; J. Gordon. Moral Philosophers Are Moral Experts! A Reply to David Archard. Bioethics 2012; 26 (10)

${ }^{10}$ L. Rasmussen. An Ethics Expertise for Clinical Ethics Consultation. Journal of Law, Medicine and Ethics 2011; 39(4): 649-61.

${ }^{11}$ A.L. Caplan, J. McCartney \& D. Sisti, eds. 2006. The Case of Terri Schiavo: Ethics at the End of Life. New York, NY: Prometheus.

${ }^{12}$ British Broadcasting Corporation News (BBC). 2009 Mar 05. Pair Die Together At Swiss Clinic. London, UK: BBC. Available at : http://news.bbc.co.uk/2/hi/uk_news/england/bristol/somerset/7927318.stm [Accessed 27 Aug 2012].
} 
If rendering judgments of right and wrong is problematic, what better alternative exists to help resolve difficult moral quandaries in an ethics consultation? The alternative to verdictbased recommendations is: clinical ethics mediation and facilitation.

Mediation is a process of facilitated conversation between disputing parties, in which the stakeholders work together to create a shared resolution to a particular dilemma that meets the needs of all of the individuals involved. ${ }^{13}$ Mediation has long been recognized an important feature of the best practice guidelines for American ECSs defined by US bioethics organizations, which advocates for a "facilitation approach." 14 Others have made similar arguments that facilitation and mediation are the ideal procedures for the resolution of clinical ethics disputes. ${ }^{15}$ These guidelines also repeatedly caution ECSs not to "usurp moral decision-making authority or impose their values on other involved parties." 16

The problem, then, with American ECSs is not that an alternative process for resolution of ethical disputes has yet to be identified, but that it has rarely been adopted - or exported. As American-style ethics consultation spreads abroad, institutions considering the implementation of an ECS should be wary of merely importing a system that may be seriously flawed.

\footnotetext{
${ }^{13}$ D.B. Stone, T. Patton, S. Heen eds. 1999. Difficult Conversations: How to Discuss What Matters Most. New York, NY: Penguin Books.

${ }^{14}$ M.P. Aulisio et al, op cit. note 4; Clinical Ethics Consultation Affairs Committee, op cit. note 4; ASBH, 2011. Core Competencies for Healthcare Ethics Consultation $2^{\text {nd }}$ ed . Glenview, IL: ASBH: 7.

${ }^{15}$ A. Fiester. Ill-Placed Democracy: Ethics Consultations and the Moral Status Of Voting. J Clin Ethic 2011; 22: 2532; A.L. Caplan \& E.J. Bergman. Beyond Schiavo. J Clin Ethic 2007; 18: 340-345; N.D. Dubler, \& C. Liebmann eds. 2011. Bioethics Mediation: A Guide to Shaping Shared Solutions. Nashville, TN: Vanderbilt University Press; A. Fiester. The Failure of The Consult Model: Why "Mediation" Should Replace "Consultation." Am J Bioeth 2007; 7: 31-32; A. Fiester. Mediation and Aporia. J Clin Ethic 2007; 18: 355-356; A. Fiester. The "Difficult" Patient Reconceived: An Expanded Moral Mandate for Clinical Ethics. Am J Bioeth 2012; 12: 2-7; M. Kahn. What Would Osler Do? Learning from "Difficult" Patients. N Engl J Med 2009; 361: 442-3; D. Knesper D. My Favorite Tips for Engaging The Difficult Patient on Consultation-Liaison Psychiatry Services. Psychiatr Clin North Am 2007; 30: 245-252.

${ }^{16}$ ASBH. 1998. Core Competencies for Healthcare Ethics Consultation $1^{\text {st }}$ ed . Glenview, IL: ASBH: 7.
} 